R. Alton Gilbert is a vice president and banking advisor at the Federal Reserve Bank of St. Louis. Robert Webb provided research assistance. The author thanks William Emmons, Ronnie Phillips, Ed Stevens, and David Wheelock for their comments on earlier drafts of this paper. Errors or omissions remain the author's responsibility.

\section{Did the Fed's Founding Improve the Efficiency of the U.S. Payments System?}

\section{R. Alton Gilbert}

T he payment functions of central banks vary among nations. Some central banks provide only limited payment services, such as issuing and redeeming currency and facilitating settlement among members of payments systems by transferring reserve balances. ${ }^{1}$ In the United States, the Federal Reserve has been a provider of payment services since the early 1900 s. By 1918, the Fed had acquired a large share of the nation's check-collection activities, especially in clearing interregional checks, and the Fed had begun processing wire transfers of reserves among banks.

The Federal Reserve recently has been re-examining the appropriateness of its role in processing checks and automated clearinghouse payments (Rivlin 1997). To provide a more complete background for these deliberations, this article examines the validity of arguments for the Fed's initial entry into its payment activities. Before the Fed was established, critics of the operation of the payments system argued that interregional check collection (collecting and paying banks located in different communities) was inefficient; they maintained that indirectly routing checks to avoid exchange charges by paying banks lengthened the collection process and resulted in higher operating expenses for banks than more direct routing from collecting banks to paying banks.

An evaluation of whether Reserve Bank services made the payments system more efficient rests on the nature of the payments system prior to the Fed's formation. Therefore, the first section of this article describes the payments system before Congress established the Fed, and the second section develops a theoretical framework for examining the effects of innovations on payments system efficiency. Subsequent sections describe the legal foundation of the Fed's collection services, trace the devel opment of Reserve Bank services, and examine the evidence for and against the argument for improved payments system efficiency.

\section{PAYMENTS SYSTEM OPERA- TION PRIOR TO 1914}

This section focuses on payment instruments and methods of collection in the United States from the Civil War until the formation of the Fed in 1914 (the National Banking Era).

\section{Payment Instruments}

Prior to the Civil War, the most important means of payment was currency. The dollar value of currency in the hands of the public exceeded the value of deposits, and the dollar value of currency payments exceeded the value of payments by check. After the 1850s, in contrast, checks became more important than currency. The dollar value of deposits exceeded that of currency, and the value of transactions settled with checks exceeded that settled with currency (Spahr 1926, pp. 84-98).

By the 1870s, currency consisted of coins minted by the federal government, U.S. notes first issued during the Civil War, and national banknotes. Federal legislation in the 1860s taxed out of existence the notes of state-chartered banks. Customers of national and state-chartered banks,

\footnotetext{
${ }^{1}$ For instance, the Bank of Canada has this kind of limited role in the Canadian payments system, which is operated by the Canadian Payments Association. Bank for International Settlements (1989) describes the roles of central banks in the payments systems of several nations.
} 
2 Some drafts were created by individuals or businesses, drawn upon the bank accounts of other individuals or businesses, and deposited with the creators' banks for collection. Such drafts were not common. Banks would process them only if the payor and payee were well known to the paying and collecting banks and the banks were familiar with the business arrangement between payor and payee.

${ }^{3}$ See Garbade and Silber (1979). Howard and Johnson $(1910$, p. 117) lists the cost of shipping currency between major financial centers as follows: between New York and Chicago, 50 cents per $\$ 1,000$; between St. Louis and New York, 60 cents; between New Orleans and New York, 75 cents'; and between San Francisco and New York, \$1.50.

${ }^{4}$ Phillips (1997) argues that the Fed's services made the payments system less efficient by encouraging bank customers to maximize float by using checks rather than drafts. A problem with Phillips' analysis is that the use of checks for interregional payments predated the formation of the Fed, although Fed senvices may have stimulated an even greater use of checks for interregional payments.

${ }^{5}$ For more details on the history of check-collection practices and the effects of Reserve Bank payment services, see Jessup (1967), Magee (1923), and Preston (1920). however, settled a large share of their payment obligations with checks and drafts drawn upon the deposit liabilities of banks.

To understand the operation of the U.S. payments system during the National Banking Era, it is necessary to distinguish between checks and drafts. Bank depositors created checks payable to those with whom they wished to settle obligations. The bank that accepted a check for collection would then seek payment from the bank on which the check was drawn. Drafts, in contrast, were written by banks. ${ }^{2} \mathrm{~A}$ bank might draw a draft upon itself or upon an account that it maintained at another bank. When making a payment in a distant city, a bank customer often purchased from his local bank a draft drawn on a bank in a major financial center. The bank on which the draft was drawn would be better known to the payee than the bank that had created the draft. In addition, the costs of collection borne by the payee would be smaller for a draft drawn upon a bank in a financial center than for a check drawn upon the deposit account of the payor.

Selling drafts was a source of revenue for banks, since customers paid banks more than the face amount of the drafts. The business of selling drafts involved the expense of maintaining balances with the banks in major financial centers. When drafts cleared, generally through clearinghouses in the financial centers, the banks on which they were drawn would debit the accounts of the banks that had sold the drafts.

Banks often used transactions in local markets for domestic exchange to replenish their balances with banks in the financial centers. Banks located in various communities established these markets for trading their coin and currency with other local banks that had balances due from banks located in financial centers. The rates of exchange in these markets fluctuated over time. Sometimes there were discounts on coin and currency and sometimes there were premiums. The limits on these exchange rates were determined by the cost of shipping coin and currency among cities, a service provided by express companies. ${ }^{3}$ These domestic exchange rates for various cities were published in the local newspapers.

W hile the available data on payments do not distinguish between checks and drafts, descriptions of banking practices indicate that, early in the National Banking Era, individuals and businesses generally made payments outside their communities with drafts purchased from their banks that were drawn on banks in major financial centers. Over time, it became more common for individuals and businesses to settle their interregional obligations with checks drawn upon their own accounts at their local banks.

Preston (1920, p. 566) and Jones (1931, pp. 172-73) date the use of checks for interregional payments to around 1890 . One indication of when this change occurred is the timing of actions by banks in major financial centers for collecting checks drawn on banks outside of these financial centers. Spahr (1926, pp. 119-30) lists a series of proposals and actions by banks to collect out-of-town checks, beginning in 1885. In 1899, the clearinghouses of New York and Boston implemented plans for collecting out-of-town checks. The New York plan attempted to eliminate al together the use of out-of-town checks for settlement of payments in N ew York City. The Boston plan, which was more successful, attempted to impose collection at par (face amount) for all checks drawn upon banks located throughout New England. From the timing of these actions, we can infer that a major shift in interregional payments-from drafts to checks- occurred around the end of the last century. ${ }^{4}$

\section{Methods of Collecting Checks}

As the number of check transactions during the National Banking Era grew, a system for clearing these checks among thousands of banks had to be developed. ${ }^{5}$ The method of collecting checks depended on the distance between the collecting and paying banks. Banks collected checks drawn upon banks in their communities through local clearinghouses or by presenting the checks at the place of 


\section{DID NONPAR BANKS EARN ECONOMIC RENTS?}

Evidence suggests that banks earned economic rents from exchange charges. Nonpar banks tended to be outside of urban areas, and when their depositors sent checks to payees outside their communities, getting these checks back to their banks was slow or expensive. Jessup (1967) indicates that banks which continued to impose exchange charges several decades after the Fed launched its collection system were primarily small banks in isolated communities of states that restricted branch banking. Also, banks tended to eliminate exchange charges when par banks opened offices in

business of the paying banks. Typically, banks collected these local checks quickly and at par.

Collecting checks involved more time and expense when the paying bank was located in a different community. Moreover, the nature of banking law contributed to the time and expense of interregional check collection. While banking law required that banks pay at par for checks presented at their place of business, banks could pay less than par for checks presented to them by mail or other indirect means. The rationale for this deduction from the face amount, called an exchange charge, was that paying banks could incur certain expenses in remitting payment to out-of-town collecting banks, including the cost of transporting coin or banknotes to the collecting banks. But when the staff of collecting banks or their agents personally presented the checks to the paying banks, they assumed the expense of transmitting the cash to the collecting banks.

Delays created another expense for collecting banks. Under banking law, a paying bank that received checks through the mail became the collecting agent for the bank that had sent the checks. The paying bank was therefore responsible for obtaining payment from itself. As a result, paying banks often remitted funds to collecting banks several days after receiving checks through the mail. their communities. The banks that resisted the Fed's plan were primarily relatively small banks in areas remote from financial centers. One interpretation of their resistance to the Fed's plan might be that the Fed attempted to deprive banks of revenue necessary for covering their cost of making payments to the Fed. In 1918, however, the Fed offered to pay the transaction expenses for nonmember banks, if such banks agreed to pay the Fed at par. This offer did not el iminate nonpar banks' resistance to Fed efforts to establish a national system for collection at par.

It was considered negligence for a bank to collect checks by sending them to paying banks through the mail (Spahr 1926, p. 104). Depositors could argue legally that a bank which mailed checks to out-of-town paying banks should absorb any exchange charges and credit the accounts of depositors at par because the bank had been negligent in its collection practices.

Collecting banks attempted to minimize delays, exchange charges, and claims of negligence by using correspondent banks to collect checks drawn upon banks located outside their communities. These correspondent banks competed for checkcollection business, and in attempting to give collecting banks the best terms (quickest collection at the lowest exchange charges), they developed methods to limit the exchange charges imposed by paying banks. The correspondents developed networks of banks that acted as their agents in presenting checks over the counter to banks that set relatively high exchange charges. In collecting through correspondents and their agents, depository banks might receive less than the face amount of checks, but more than if the checks had been sent to the paying banks through the mail. Also, depositors in the collecting banks would not have legal grounds for charging the banks with negligence in their collection practices.

The indirect routing of checks to paying banks through the agents of corre- 


\section{THE ROLE OF EXPRESS COMPANIES IN CHECK COLLECTION}

By using the services of express companies, banks could have collected checks at par without the indirect routing that was so common before the Fed introduced its check-collection services. Employees of the express companies could take checks to the paying banks, demand payment at par, and return to the collecting banks with the funds. But histories of check collection prior to the formation of the Fed do not mention such arrangements. An extensive discussion of the use of express companies involves the Reserve Banks' collection of checks drawn upon nonpar banks. Prior to a key ruling by the U.S. Supreme Court in 1923, the Reserve Banks accepted for collection checks drawn upon all banks, including those that refused to pay the Fed at par. One of the Fed's objectives in accepting checks drawn upon these nonpar banks was to make its collection service as useful as possible for the banks that chose to collect checks through the Fed. In some cases, express agents were the only means available to the Fed of obtaining par collection from nonpar banks. Descriptions in Harding (1920) indicate that the Reserve Banks generally accumulated at least $\$ 100$ in checks drawn upon a nonpar bank before delivering them to an express company for collection. The Fed's justification for accumulating checks drawn upon nonpar banks was to limit collection costs; a statement by Harding indicates that express companies had a minimum charge of 10 or 15 cents per item for checks in denominations as low as $\$ 5$. Charges per item were smaller when the Fed had $\$ 100$ or more to collect from a paying bank. These minimum charges may indicate why private banks did not often use express companies for collecting of out-oftown checks. The Fed's collection practices reflected its objective of establishing collection at par as the national standard, not the objective of profit maximization.

ments with the paying banks on these par lists. In some cases, the correspondents were paid at par for checks drawn upon accounts of depositors in the paying banks. In addition, the banks on these par lists often served as agents for their correspondents in obtaining collection at par from other banks in their communities (Vest 1940, p. 90). Other correspondents, in contrast, offered to pay exchange charges on checks that they sent to banks for collection, and to credit the accounts of these banks at par for checks received from them. The respondents paid for this service by maintaining balances at the correspondents (Tippetts 1929, pp. 258-59). Some banks maintained balances with several correspondents in major cities so they would receive exchange charges on almost all of the checks presented to them by out-of-town banks (Willis 1951, pp. 7-9).

The savings in operating expenses and interbank balances that resulted from using correspondents' collection services 
were limited by the large number of banks and the complexity of correspondent banking relationships. A depository bank or its correspondent had to maintain lists of paying banks for which correspondents provided par collection, and they had to route checks to the appropriate correspondents. Unless the correspondents of the depository and paying banks maintained balances with each other, a check would pass through other intermediaries with which these correspondents maintained accounts. A check might pass through several banks in the collection process. Thus, the arrangements for collecting interregional checks through correspondents encouraged indirect routing of checks and forced a complex matrix of interbank balances to facilitate the collection system. ${ }^{6}$

Banks in some cities attempted to cooperate in coping with the challenge of collecting out-of-town checks. For instance, the Boston clearinghouse established a plan in 1899 for par collection of checks drawn upon all banks located in New England (Hallock 1903). The plan, modeled after the earlier Suffolk system for the circulation of banknotes at par (Spahr 1926, p. 127), was largely successful. ${ }^{7}$ While some rural banks in N ew England did not join the par collection system, approximately 97 percent of checks in N ew England were collected at par (Spahr 1926, pp. 126-29).

Members of the $\mathrm{N}$ ew York clearinghouse, in contrast, agreed to impose high fees on customers who deposited checks drawn on out-of-town banks. Their objective was to eliminate the use of out-of-town checks for payments in N ew York City. The banks agreed to charge a minimum fee of 10 cents per check, with higher fees on relatively large out-of-town checks. The penalty for a bank that cheated on this agreement was $\$ 5,000$ for a first offense and expulsion from the clearinghouse for the second offense (Spahr 1926, pp. 12526). N ew York firms, however, continued to accept out-of-town checks in payment, collecting the checks through correspondent banks located in other financial centers, often with longer collection periods and higher expenses than would have been possible if the $\mathrm{N}$ ew York banks had collected the checks.

The inefficiencies of the payments system that resulted from this collusion among N ew York City banks might have been remedied through antitrust enforcement, rather than through government involvement in check collection. But when the Fed was founded, such collusive agreements among banks were common, and they were not subjected to antitrust enforcement. For instance, members of clearinghouses often agreed on the maximum interest rates they would pay on deposits (Cannon 1910, pp. 11-23).

The check-collection process created settlement obligations among banks in different communities. If the banks did not hold balances with each other, they generally settled among themselves with drafts drawn upon banks in major financial centers. The most important center was N ew York City; drafts drawn upon $\mathrm{N}$ ew York banks served as the national currency for interbank settlement. ${ }^{8}$ This method of settlement relied on the operation of markets for domestic exchange, through which banks in the same community traded coin and currency for balances due from banks in New York City (Hallock 1903).

\section{PAYMENTS SYSTEM EFFI- CIENCY: A THEORETICAL FRAMEWORK \\ To examine the implications of} Reserve Bank services for payments system efficiency, one needs to develop a framework for defining efficiency. The framework in this article is based on that developed by Berger, Hancock, and Marquardt (1996), hereafter BHM. Their analytical framework, derived from welfare theory, emphasizes a trade-off between risks and costs in the payments system, and the effects of innovations on this trade-off. This section describes the framework and uses it to examine issues in payments system efficiency around the time the Fed was founded.

\footnotetext{
${ }^{6}$ Weinberg (1997, p. 39) argues that the circuitous routing of checks prior to the formation of the Fed does not necessarily indicate that the check-collection networks operated by correspondents were inefficient. While these networks may have been efficient under the existing constraints on bank behavior and legal relationships between collecting and paying banks, such an argument does not prove that the collection system could not be made more efficient through regulatory changes ( such as permission for nationwide branch banking) or government provision of clearing services.

${ }^{7}$ For analysis of the Suffolk system, see Calomiris and Kahn (1996) or Rolnick, Smith, and Weber (in this issue).

${ }^{8}$ Citing a survey of national banks in 1890, the Comptroller of the Currency $(1890$, p. 16) reported that 63.1 percent of bank drafts (dollar value) were drawn upon banks in New York City, compared with 9.4 percent on banks in Chicago and 1.6 percent on banks in St. Louis.
} 


\section{Figure 1}

The Risk-Cost Frontier for the Payments System

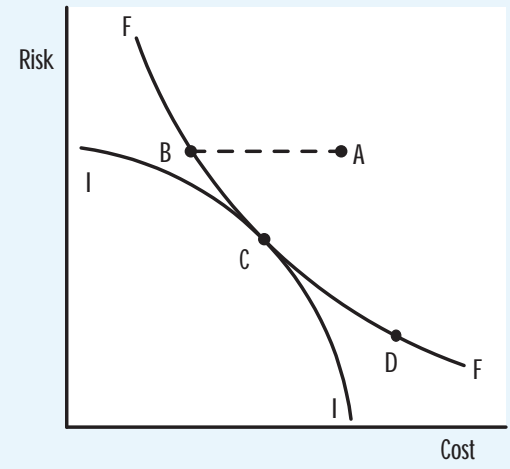

\section{Basic Features of the Framew ork}

Figure 1 illustrates the theoretical framework. The axes measure the risk and costs borne by payors, payees, and related parties. The risk borne by any one party reflects the distribution of that party's payments-activity losses; the vertical axis in Figure 1 measures some combination of these risk measures for all the parties bearing such risks. Similarly, the horizontal axis measures the weighted sum of costs borne by all the parties.

The curve FF represents the frontier of minimum risk in operating the payments system for a given cost and the minimum cost for a given risk. The position of the curve depends upon the technology used to process and settle payments, financial techniques for monitoring and controlling risk, and the regulatory environment, all of which may be altered by innovations. Thus, BHM classifies innovations in the operation of the payments system as technological, financial, or regulatory innovations. The convex shape of the frontier reflects the usual assumption of diminishing marginal returns- as risks get lower (moving toward the horizontal axis), the marginal costs of further risk reductions increase. All of the points in the area above and to the right of the efficient frontier, $\mathrm{FF}$, as well as those on the frontier, are feasible outcomes. Points off the frontier, however, reflect inefficient choices from a social viewpoint, in that both risk and costs could be reduced. For instance, the risk and cost combination $A$ is inefficient; the cost of operating at the same level of risk on the frontier (point B) would be lower.

Curve II reflects the social utility function. Since greater risk and greater cost reduce social welfare, shifting curve II to the left increases social welfare (lower cost for given risk). Given the frontier curve FF, the point of highest social welfare is represented by point $\mathrm{C}$, where the II and FF curves are tangent. Innovations improve payments system efficiency if they shift society to a higher indifference curve.

BHM develops this framework with rather general concepts of risk and cost. This section describes the U.S. payments system prior to 1915 using the BHM framework.

\section{The Nature of Risk and Cost in Payments System O peration}

Point $D$ on the FF frontier reflects the minimum cost associated with an arrangement in which all payments are made in cash. Risk would be low, but cost would be high, especially for interregional payments. While point $D$ is on the FF frontier, it does not represent the point of maximum social welfare because of the high cost of minimizing risk with cash payments. Other payment arrangements, based on the use of checks and drafts, involved more risk: the possibility of losses from bad checks, from account closures for insufficient funds, and from bank failures. The observation that not all payments were settled in coin and currency prior to 1915 indicates that, to economize on the cost of settling payment obligations, individuals and firms were willing to accept more than the minimal level of risk illustrated by point $D$.

The Comptroller of the Currency (1890) and Garbade and Silber (1979) mention that innovations in communications and transportation over time reduced the cost of transporting coin and currency over long distances. In the framework of BHM, these technological 
innovations cause the FF curve to shift to the left over time (greater efficiency of the payments system) by reducing the cost associated with minimum risk (all payments in cash). In addition, the Comptroller of the Currency (1890) indicated that the fees banks charged for drafts drawn upon banks in financial centers declined sharply over time. In terms of this theoretical framework, technological innovations tended to enhance social welfare by reducing the cost of interregional payments.

The relevant operating costs of the payments system in this analysis are as follows:

1. The cost of transporting coin and currency (one option for settling obligations).

2. The cost of collecting checks, including the cost (borne primarily by correspondent banks) of routing out-of-town checks to paying banks.

3. The cost of operating the markets for domestic exchange that existed prior to the formation of the Fed.

\section{The opportunity cost of holding} cash balances.

\section{Exchange Charges and Social Welfare}

Given the prominence of exchange charges in Fed policies for payments system operation, their role in the framework of Figure 1 deserves special attention. Since exchange charges were a cost to some banks and bank customers, should we include them in the measure of cost in Figure 1? If so, eliminating exchange charges would tend to shift the FF curve to the left, increasing social welfare. In contrast, banks that imposed exchange charges viewed Reserve Bank activities to promote check clearance at par as a threat to their welfare. How should our measure of social welfare reflect their view of what was in their interest?

BHM (p. 701) mentions that some participants might prefer an inefficient arrangement for the payments system (a combination of risk and cost off the FF curve) if that arrangement would impose the extra costs or risk on other participants. Thus, changes in payment arrangements that enhance efficiency are not necessarily in the interest of each participant in the payments system.

$M$ any banks located outside urban areas resisted the Fed's plan for national par clearance of checks, since they wanted to maintain their revenue from exchange charges. ${ }^{9}$ Their resistance, however, does not necessarily indicate that the Fed's system reduced social welfare.

On the other hand, eliminating exchange charges would not necessarily increase welfare. Welfare theory focuses on the implications of changes in market practices for the pricing of goods and for the quantity of market output, not on the effects of such changes on the distribution of profits among firms that sell the goods (Scherer 1970, pp. 8-38). Exchange charges affected the allocation of profits among banks, in that they were revenue to some banks and expenses to others. Exchange charges would reduce welfare if the efforts by participants to avoid such charges increased the cost of payments system operation (for a given level of risk) above the level of cost that would have been possible without the charges.

\section{Effects of Reserve Bank Payment Services and the Discount Window on System Efficiency}

The inherent risks in the payments system before the establishment of the Fed included disruptions created by banking panics. For example, when banks in major financial centers suspended currency payments in response to panics, they restricted depositors' currency withdrawals. Bank failures resulting from such panics also disrupted the system. A major purpose for establishing the Fed was to eliminate panics by providing banks with reserves through the discount window during liquidity crises (Dwyer and Gilbert 1989).

The Fed could have reduced risk in the payments system through its discount
${ }^{9}$ Reserve Bank services reduced substantially the role of drafts drawn upon New York City banks in the settlement of interregional obligations. After the Fed established its collection system, however, the nonpar banks located outside urban areas, not the New York City banks, opposed the Fed's collection system. 
window operations without providing payment services. The purpose of this article is to assess the implications of Reserve Bank payment services in terms of risk vs. cost, independent of the effects of discount window operations.

The chall enge of separating these effects of Fed policies is illustrated in Figure 1. Let us suppose that point A in Figure 1 represents the risk-cost combination for the payments system under the banking laws and regulations of 1913, with the addition of a central bank-operated discount window but no central bank payment services. This central bank would provide currency to banks that borrowed at the discount window and credit the banks' reserve accounts when they deposited currency, but it would not provide wire transfer services, interbank settlement through debits or credits to reserve accounts, or collection services. Now let us suppose that point $C$ on the FF curve represents the risk-cost combination with all of the above, plus Federal Reserve Bank payment services. W hat kind of influences would have kept the private sector from moving to the efficiency frontier on its own? What was special about the Fed that enabled it to improve the efficiency of the payments system?

The Reserve Banks did not invent a new technology for check collection. Development of their check collection service was a regulatory innovation, reflecting two aspects of the legal and regulatory environment that existed prior to the formation of the Fed.

One legal barrier to efficient check collection may have been the principal-agent relationship created when banks mailed checks to other banks for collection; that is, the paying bank became the agent of the collecting bank, responsible for collecting from itself. This legal relationship created a disincentive for banks to collect interregional checks by the most direct method, the mail service. Instead, they sent checks to correspondents, who did the collection for them.

A second legal barrier to efficient operation of the system may have been restrictions on nationwide branch banking. If the major correspondent banks had offices located throughout the nation, they could have routed checks directly to their own offices that were nearest to the offices of the paying banks and had their employees present the checks for par collection. Instead, correspondents had to develop ad hoc arrangements for getting checks to paying banks through networks of correspondents and respondents. The Reserve Banks, with their nationwide network of offices and legal authority to demand remittance at par from member banks, may have reduced the cost of interregional check collection by reducing operating expenses and shortening collection times. In addition, shorter collection times may have reduced risk by reducing the possibility that checks would be dishonored or that the paying bank would fail prior to settlement. A later section examines the evidence for and against the hypothesis that the Federal Reserve's collection services improved payments system efficiency.

\section{Relevant Comparisons in Assessing Fed Services Efficiency}

In evaluating the evidence, it is important to make appropriate comparisons. It is possible that payments system efficiency would have been more improved if Congress had permitted nationwide branch banking instead of authorizing the Reserve Banks to offer payment services. In Figure 1, if $\mathrm{FF}$ reflects the efficient frontier for the payments system given Fed payment services and restrictions on branching as of 1913, nationwide branch banking (with or without Fed services) might have shifted the frontier farther to the left. The evidence in this article, however, does not allow us to explore that hypothesis.

It is also possible that the Reserve Banks' entry into the payments business precluded future innovations by the private sector that would have shifted the FF curve farther to the left in the absence of Reserve Bank services. While the Fed has encouraged innovation in the operation of the payments system in recent decades (Summers and Gilbert 1996, 
pp. 17-18), the evidence cited in this article is not relevant for judging whether Reserve Bank participation in the payments system has, on net, retarded or enhanced payments system efficiency over the many years since the Fed's founding.

Finally, in assessing the limitations of the data, one should note a critique of Reserve Bank payment services by Baxter (1983). He developed an economic theory of relationships among payors, payees, and their banks (assuming they use different banks for payment services). In modeling the demand for payment services, Baxter notes that a transaction involves a joint demand by payor and payee for method of payment and, on the supply side, the cooperation of two banks. Baxter notes that the arrangement that maximizes welfare is likely to involve a side payment, or "interchange fee," between the two banks. He also argues that in a payments system with many payors, payees, and banks, negotiations among these parties over the allocation of costs and fees for each transaction would be inefficient. Thus, he argues that an efficient payments system will have some standard practice for interchange fees among banks.

Baxter describes arrangements in credit card associations as reflecting efficient pricing in a segment of the payments system. In contrast, Baxter (1983, p. 571) criticizes the Federal Reserve for imposing par clearance in the check collection system:

Thus the role of the exchange fee in the process of check clearance, a commercial context in which an unregulated market solution might have been expected to work reasonably well and to yield instructive results, was aborted and continues to be suppressed by a mixture of subsidies and coercion by the Federal Reserve System.

Baxter does not attempt to prove that check collection at par was inefficient. Rather, he suggested that interchange fees in check collection might have been necessary for maximum efficiency in payments system operations. Baxter notes, however, that prior to the formation of the Fed, members of clearinghouses cleared checks among themselves at par. The clearinghouses would have been free to set interchange fees among their members if they felt that such fees would make the payments system more efficient.

There is an important reason why clearinghouses cleared checks at par: The common law requirement that a bank pay at par when checks drawn upon its depositors' accounts were presented at its place of business. This legal standard for par collection limited pricing options for clearinghouses. Since clearinghouses are cooperatives set up to avoid the cost of bilateral exchange, they could not function effectively if members could avoid paying interchange fees by presenting checks directly to each other. Credit card associations are effective in imposing interchange fees because their members do not have the option of collecting credit card receivables from each other directly at par. The courts limit the rights of banks with credit card receivables to the rights specified by their card associations.

Baxter's framework suggests that changing banking law to el iminate the requirement for banks to remit at par for checks presented at their place of business might have led to greater payments system efficiency than did the Reserve Banks' entry into the payments system. Eliminating the requirement for payment at par might have facilitated private-sector development of check-clearing organizations similar to today's national credit card associations. These check-clearing organizations would have set the interchange fee for maximum payments system efficiency, thus shifting the FF curve to the left.

In considering the effects of Reserve Bank operations on payments system efficiency, we should note that the Fed did not have the prerogative to eliminate the requirement for paying banks to remit at par for checks presented at their place of business. While Baxter's theoretical framework is interesting, his critique of the Fed is not relevant for judging whether Reserve 
Bank operations improved the efficiency of the payments system, given the legal and regulatory environment in place when the Fed was founded.

\section{LEGAL FOUNDATION FOR RESERVE BANK COLLEC- TION SERVICES}

The history of the Fed's role in the payments system has been shaped largely by acts of Congress and litigation. In tracing this history, it is necessary to examine the legal foundation of the Fed's role in the payments system in some detail. The Federal Reserve Act (FRA) as enacted in 1913 did not state clearly the Congressional intent for the Fed's role in the payments system. Section 13 authorizes the Reserve Banks to receive checks from any member banks drawn upon other member banks. Section 16 states that Reserve Banks shall receive checks from member banks at par, and it authorizes the Board of Governors to establish a clearinghouse for clearing checks and drafts among the Reserve Banks. Did these sections simply direct the Fed to provide payment services to member banks, or did they provide the Fed with a mandate to make the collection of checks at par the national standard for the banking industry?

These sections of the FRA have been subject to various interpretations. From its earliest beginnings, the Board of Governors interpreted them as giving the Fed a mandate to establish a national system for par clearance of checks. In a recent review of the legislative history of the FRA, however, Stevens (1996) concludes that the Fed's founders did not see a need for a government service to deal with inefficiencies in the nation's check-collection system. Rather, Stevens argues that the founders included these sections in the FRA on check collection to make reserve balances useful for member banks. In Stevens' argument, the founders were concerned that banks would resent the opportunity cost of holding idle balances at the Reserve Banks, and their resentment might undermine the Fed's effectiveness in providing an elastic currency and acting as lender of last resort in financial crises. Stevens argues that the collection system was to be the glue that tied banks to the Fed. In drawing this conclusion, he emphasizes some statements by the founders about the need to make reserve balances useful for members. $\mathrm{He}$ also cites the fact that sections dealing with check collection were added to legislation for a central bank late in the legislative process. ${ }^{10}$

An amendment to the FRA in June 1917 helps clarify Congressional intent involving the Reserve Banks' check-collection services. One provision allowed nonmember banks to become clearing members of the Reserve Banks. These clearing members could present checks at their Reserve Banks for collection if they held clearing balances. Proceeds from collecting the checks would be credited to the clearing account, and the value of checks that were received by the Reserve Bank and drawn upon the clearing member would be charged to its clearing account.

A second provision of the amendment as originally proposed by Senator Hardwick would limit bank exchange charges to no more than one-tenth of 1 percent ( 10 cents per $\$ 100)$ of the face value of a check. The proposed legislation would have permitted member banks to impose exchange charges, within the specified limit, on the Reserve Banks. While the bill was in conference (versions having passed the House and Senate), President Wilson intervened in a letter to Senator Hardwick:

I should regard such a provision [Reserve Banks absorbing exchange charges in their check collection activities] as most unfortunate and as almost destructive of the function of the Federal reserve banks as a clearing house for member banks, a function which they have performed with so much benefit to the business of the country (Vest 1940, p. 91).

Because of Wilson's intervention, the conferees modified the section on exchange charges by adding that "no such charges 
shall be made against the Federal Reserve banks" (Vest 1940, p. 91). This amendment to the FRA indicates that Congress viewed the Fed's check-collection system as more than just a means of giving member banks some value for their required reserves. If Congress had included provisions for a check-collection system in the FRA in 1913 just to make membership in the Fed attractive, why would Congress grant nonmember banks access to the clearing system in 1917?

Exchange charges against the Reserve Banks would not have undermined the purpose of giving member banks some value for their reserve balances, since industry practice involved paying exchange charges. ${ }^{11}$ The Fed's collection system could have continued to serve as the glue binding member banks to the Fed. President Wilson's intervention, however, indicates that he considered the Fed's par collection system a valuable service to the nation. In modifying the bill to prohibit exchange charges against the Reserve Banks, Congress assented with this view. ${ }^{12}$

The other major legal developments that shaped the nature of the Fed's collection services involved litigation challenging the Reserve Banks' efforts to establish par collection as standard practice throughout the nation. In the early years of the Fed's collection system, the Reserve Banks accepted checks drawn upon all banks, including those that had not agreed to pay the Fed at par. The Reserve Banks used a variety of methods to collect at par from these nonpar banks, including hiring express agents to travel to the offices of the nonpar banks, present checks over the counter, and return with the funds. Some of the nonpar banks interpreted the Fed's collection practices as attempts to harass them into agreeing to pay the Fed at par. ${ }^{13}$ Nonpar banks challenged the Fed's collection practices in the courts, and a decision by the Supreme Court of the United States was announced in 1923. The Court ruled that since Congress did not require the Fed to establish a national system of par collection for checks, the Reserve Banks could not compel nonmember banks to pay them at par. In response to this Court ruling, the Reserve Banks restricted the checks they would accept for collection to those drawn on the banks that agreed to pay the Fed at par. Banks had to use other channels for collecting checks drawn on nonpar banks.

\section{CHRONOLOGY OF RESERVE BANK PAYMENT SERVICES}

When the Reserve Banks began providing check-clearing services in 1915, the Board of Governors initially pursued what it called a voluntary collection system. The Reserve Banks would receive for collection only those checks drawn upon banks that had volunteered to join the Fed's collection system. The banks had agreed to pay at par for checks presented by the Fed for collection, even if the Fed sent the checks to the paying banks through the postal service. However, only about one fourth of the member banks joined the collection system. In its annual report for 1916, the Board expressed regret that the voluntary system had not been more successful and concluded that the voluntary plan would never achieve its objective of a universal par collection system for the U.S. economy. To promote this goal, the Board decided in A pril 1916 to change its collection plan from voluntary to compulsory for member banks. Under this new plan, the Fed required each member to remit at par for checks the Reserve Banks presented for collection, including checks sent through the mail. Member banks were not, however, required to send checks to the Reserve Banks for collection.

\section{Introduction of Collection Fees}

The Board also adopted a policy of charging banks for the collection service: Each Reserve Bank charged the depositing bank a fee per check that reflected its expenses. Initially, the fees ranged from 0.9 cents to 2 cents per check. At this time, the Fed also stopped the practice of immediately adding the value of checks to the reserve accounts of collecting banks; instead it deferred credit according to a schedule based upon estimates of the time
${ }^{11}$ Willis (1923, pp. 1062-63) asserted that passage of legislation authorizing member banks to impose exchange charges on the Reserve Banks would have destroyed the Federal Reserve check-clearing system. Willis did not, however, provide the basis for that assertion.

${ }^{12}$ The Board of Governors was uncertain whether this legislation granted the Fed authority to set limits on the exchange charges of all banks or only banks that were Fed members. The Board requested the opinion of the U.S. Attomey General, who held that the Board's authority over exchange charges under this act applied only to Fed members. Because of this ruling, the Board did not use its authority over exchange charges in its attempt to make collection of checks at par the national standard for the banking industry. See Spahr (1926, p. 200).

${ }^{13}$ See Harding (1920) for the Federal Reserve Board's response to accusations by nonpar banks about the Fed's check-collection practices. 
${ }^{14}$ Willis and Steiner (1926, p. 607) reported that on July 1 , 1925, only 158 nonmember banks in seven Federal Reserve districts maintained such clearing accounts.

${ }^{15}$ Tippetts (1924) poses the hypothesis that an option for banks to meet their reserve requirements with uncollected funds will affect bank behavior. Gilbert (1978) found evidence in the 1970 s to support this hypothesis. Prior to 1980, the state-chartered banks that did not choose to be Fed members were exempt from Fed resenve requirements but subject to state requirements. Some states permitted banks to count CIPC as part of their reserves, whereas other states excluded them. Gilbert found that nonmember banks in states that excluded CIPC from reserves reported relatively low levels of CIPC; they appeared to report their uncollected funds as demand balances due from banks, a common practice prior to the Fed's formation. it took the Reserve Banks to present the checks to the paying banks (Willis 1923, p. 1060). Under the prior plan, a collecting bank's reserve account was credited and the paying bank's reserve account was debited for the amount of the check when the Fed received the check, before the paying bank had a chance to see it or learn of the debit to its reserve account. Reserve Bank annual reports for 1916 indicated that members of the voluntary collection system had objected to this timing of debits to their reserve accounts.

Also during 1917 the Fed began allowing banks to use transfer drafts for settling their payment obligations with other banks. Banks with accounts at the Reserve Banks could create transfer drafts drawn upon their accounts, which were then payable immediately at any Fed office. M ember banks could therefore use transfer drafts for interbank settlement instead of drafts drawn upon their accounts at banks in N ew York City. For example, a bank in St. Louis would write a draft drawn upon its reserve account at the St. Louis Fed and mail it to a bank in Atlanta. The Atlanta bank would get immediate credit to its reserve account when it presented the draft to the Atlanta Fed. Settlement between the two Reserve Banks would occur daily through the gold exchange fund.

\section{Participation by Nonmember Banks}

An amendment of the FRA in 1916 permitted the Reserve Banks to collect checks drawn upon nonmember banks. In June 1917, Congress amended the FRA in response to a request by the Board to permit the Reserve Banks to collect checks for nonmember banks that opened clearing accounts at their Reserve Banks. The Fed required these clearing members to pay the Fed at par for checks drawn upon them.

Only a small number of nonmembers joined the Fed's collection system. ${ }^{14}$ Tippetts (1924, pp. 632-33) concluded that a major reason why few nonmembers took this option for check collection was the nature of state reserve requirements. N onmember banks counted balances with other banks as part of their reserves for meeting state requirements, and banks tended to count all of their funds deposited with correspondents, including uncollected funds, as balances due from banks. The Fed's accounting system, in contrast, separated cash items in the process of collection (CIPC) from balances due from the Reserve Banks. N onmember banks would thus tend to increase the burden of state reserve requirements by collecting checks through clearing accounts at the Reserve Banks. ${ }^{15}$ These banks could ben efit from the Fed's check-collection system indirectly by clearing checks through correspondents that used the Fed's collection system.

In 1918 the Fed began operating its leased wire system for reserve transfers among banks, an electronic alternative to transfer drafts. Also, in July 1918, the Board ended the policy of charging fees to banks that deposited checks with the Reserve Banks for collection. The objective for dropping the fees was to promote use of the Fed's collection system. For the nonmember banks that agreed to pay the Fed at par, the Fed began absorbing the expenses they incurred in remitting payment to the Reserve Banks. One objective of this offer was to eliminate the argument that nonmember banks could not remit at par because of the expenses they would incur in remitting payment. In response to a ruling by the U.S. Supreme Court in 1923, the Reserve Banks began refusing to accept for collection checks drawn upon nonpar banks.

\section{Volumes of Reserve Bank Payment Services}

The Reserve Banks very quickly became major processors of payments. Table 1 presents the number of checks cleared by the Reserve Banks and the dollar value of these checks relative to the value of checks cleared through the private clearinghouses. In the period around the formation of the Fed, data were available on the dollar value of checks cleared through about 200 clearinghouses in cities around the nation, 
Volume of Checks Processed by the Reserve Banks

\begin{tabular}{|c|c|c|c|}
\hline Year & Millions of Checks & $\begin{array}{l}\text { Dollar Value } \\
\text { of Checks } \\
\text { (billions of dollars) }\end{array}$ & $\begin{array}{l}\text { Value of Checks } \\
\text { Processed by Reserved } \\
\text { Banks as Percentage } \\
\text { of Checks Cleared } \\
\text { Through Clearinghouses }\end{array}$ \\
\hline 1915 & 8.8 & $\$ 4.7$ & $2.9 \%$ \\
\hline 1916 & 25.8 & 10.9 & 4.5 \\
\hline 1917 & 75.7 & 44.9 & 14.7 \\
\hline 1918 & 154.4 & 105.7 & 32.9 \\
\hline 1919 & 305.2 & 136.5 & 35.2 \\
\hline 1920 & 452.1 & 156.5 & 35.6 \\
\hline 1921 & 522.7 & 119.2 & 34.1 \\
\hline 1922 & 584.9 & 150.5 & 39.1 \\
\hline 1923 & 639.2 & 196.6 & 48.6 \\
\hline 1924 & 684.0 & 209.1 & 46.9 \\
\hline 1925 & 716.5 & 247.2 & 49.4 \\
\hline 1926 & 758.5 & 261.4 & 51.0 \\
\hline 1927 & 794.8 & 266.7 & 49.0 \\
\hline 1928 & 818.5 & 289.0 & 46.4 \\
\hline 1929 & 852.1 & 351.7 & 49.1 \\
\hline 1930 & 834.2 & 311.2 & 57.2 \\
\hline 1931 & 796.9 & 237.8 & 57.8 \\
\hline 1932 & 677.0 & 169.2 & 65.4 \\
\hline 1933 & 635.0 & 151.2 & 62.0 \\
\hline 1934 & 754.7 & 171.9 & 65.1 \\
\hline
\end{tabular}

SOURCES: Observations on check clearings by the Federal Reserve Banks are from the annual reports of the Board of Governors of the Federal Reserve System. Data on the value of checks cleared through clearinghouses are from U.S. Department of Commerce (1960, p. 640). The annual observations for the number of checks cleared by the Reserve Banks, and the dollar value of the checks, are adjusted to eliminate duplications in reports by the individual Reserve Banks. A duplication occurs if two Reserve Banks report the same item as one of their items handled. The annual reports of the Board of Governors for 1919 through 1926 provide data on items handled with and without duplications. Data for 1915-18 reported with duplications have been adjusted in accordance with data for 1919, and data for the years 1927-34 have been adjusted in light of the data for 1926.

including the major financial centers and many relatively small cities. While this series does not reflect the dollar value of all checks, it provides the broadest available measure of check clearings outside the Federal Reserve System. ${ }^{16}$

In 1915, the Reserve Banks processed 8.8 million checks, with a dollar value of $\$ 4.7$ billion, which was about 3 percent of the value cleared through the private clearinghouses. The volume of checks processed by the Fed's clearing system rose rapidly after the Fed adopted its compulsory plan in 1916 , rising to about 33 percent of the clearings through the private clearinghouses by 1918. Table 1 indicates that clearings through the Reserve Banks as a percentage of clearings through private clearinghouses continued to rise through $1934 .{ }^{17}$

Those familiar with the current infrastructure of the Fed's check-collection system - which includes a ground and air
${ }^{16}$ See Garvy (1959) for a description of the data on check clearings.

${ }^{17}$ The sharp rise in the Fed's market share after 1929 may reflect a flight to safety by respondent banks during the banking panics of the early 1930s. That is, respondent banks considered clearing checks through the Reserve Banks less risky than clearing through private correspondents. Respondent banks also behaved in this way during the 1980s; the Federal Reserve Bank of Dallas had a sharp rise in its check clearings during the Texas banking crisis (Clair, Kolson and Robinson, 1995). 
transportation network to clear checksmay be surprised by the rapid development of the Fed's check collection operation. How did a new organization put a national collection infrastructure in place so quickly?

In fact, the Fed did not create a new infrastructure to collect checks. Instead, it used the existing national infrastructure for communication: the postal service. Banks mailed checks to the Reserve Banks for collection, and the Reserve Banks mailed checks to paying banks. As explained above, banking law discouraged collecting banks from sending checks directly to paying banks, but the Fed asserted its legal authority to obtain payment at par from member banks for checks sent to them through the mail (J ones 1931, p. 138). The FRA did not al ter private banks' authority to obtain par collection from other banks. In terms of the theoretical framework presented above, the Fed's use of the postal service for check collection at par was a regulatory innovation.

\section{EFFECTS ON PAYMENTS SYSTEM EFFICIENCY}

To investigate whether evidence is

${ }^{18}$ In their assessment of the Fed's role in check collection, Duprey and Nelson (1986) mention that the Fed failed to achieve its goal of universal participation in its national system of par check collection, but they conclude that the Fed did improve the efficiency of intercommunity check collection.

${ }^{19}$ The work by Miron (1986) generated controversy. See Canova (1991), Clark (1986), Fishe (1991), Fishe and Wohar (1990), Holland and Toma (1991), and Mankiw, Miron, and Weil (1987 and 1990). There is general agreement among these authors that the seasonal pattem of interest rates in the United States changed after the formation of the Fed, with stronger consensus that the Fed changed the seasonal patterm of interest rates after 1917. consistent with the view that the Fed's payment services improved the efficiency of the payments system, this section looks at the effects on transaction costs, the national credit market, bank operating costs, cash assets, and the rapid adoption of Fed payment services by the banking industry. ${ }^{18}$

\section{Transaction Costs and the National Credit Market}

In the theoretical framework presented above, the Fed's payment services increase payments system efficiency if they shift the FF frontier in such a way that society is on a higher indifference curve, a higher level of social welfare. The most relevant evidence of increased social welfare would be a positive macroeconomic shock that could be attributed to the development of Reserve Bank payment services.

If the Fed's collection system had its intended effects, it would tend to reduce transaction costs for payments across regions. In turn, reductions in the costs of interregional transactions would tend to facilitate the operation of a national capital market, rather than separate regional capital markets, each with its own balance of supply and demand for capital. Economic historians have examined the process by which the national integration of capital markets occurred by tracing patterns in regional interest rate differentials (James 1978).

An important challenge in investigating the effects of the Fed's collection system is to focus on effects that cannot be attributed to other aspects of Fed operations. To the extent that the Fed's formation promoted the integration of regional capital markets into a national market, the discount window may have been more significant than the Reserve Bank collection system in reducing transaction costs. Miron (1986) attributes a change in the seasonal pattern of interest rates after the formation of the Fed to the operation of the discount window. ${ }^{19}$ The rest of this section focuses on evidence that can be tied more directly to the operation of the Fed's collection system.

\section{0 perating Costs}

In terms of the theoretical framework, evidence of increased efficiency in the operation of the payments system would include reduced operating costs for banks-for instance, smaller ratios of operating expenses to total assets and lower ratios of employees per dollar of assets. Unfortunately, such data are not available for the period around the time when the Federal Reserve was founded.

\section{Cash Assets}

One cost component in the payments system was the opportunity cost to banks of holding cash assets. Banks had two major reasons for holding cash in their vaults and balances with other banks: to facilitate payment-order processing and to meet reserve requirements. If the Fed's payment services improved the efficiency of the payments system, we should be able 
to find evidence that the services allowed banks to operate with smaller percentages of their assets in cash, independent of the effects of changes in reserve requirements.

Fed payment services may have permitted banks to operate with lower cash ratios for the following reasons. First, cash holdings, which included uncollected funds, would decline to the extent that the Fed's check-clearing operations reduced the number of days required for checks to clear by eliminating indirect routing of checks to paying banks. Second, Fed payment services may have reduced the interbank balances that banks needed to maintain for clearing checks, since they could send checks to the Fed for collection.

An important challenge in assessing the effects of the Fed's payment services on bank cash holdings is to separate their effects on indicators of payments system efficiency from the effects of other changes unrelated to the Fed's payment services. The FRA reduced reserve requirements substantially for national banks, which were required to be Fed members. The Comptroller of the Currency (1915) calculated the reductions in required reserves for national banks as follows: 28 percent for national banks located in central reserve cities, 41 percent for banks in reserve cities, and 26 percent for national banks located elsewhere (see appendix for details). In addition, there was a reduction in required reserve ratios for Fed members in 1917. Because these changes occurred around the time the Fed developed its payment services, this section examines the effects of the Fed's payment services on the cash ratios of state-chartered banks.

A bout half of the states reduced their reserve requirements around the time the Fed was founded (see appendix). This division creates a type of experiment: If the cash ratios of state-chartered banks declined around the time the Fed developed its payment services, were the declines limited to banks in states that reduced their reserve requirements?

Figures 2 and 3 present the rel evant ratios of cash to total assets for the years 1900 through 1930. Figure 2 presents cash ratios for national and state-chartered banks in states that lowered their reserve requirements in the years 1913 through 1925 (see appendix for the list of states). A wide gap exists between the cash ratios of national and state-chartered banks prior to the Fed's formation. Cash ratios of national and state-chartered banks declined sharply around the time the Fed was founded. Because of the reserve-requirement reductions, it is not possible to attribute the cash-ratio reductions in Figure 2 to the introduction of the Fed's collection system. ${ }^{20}$

Figure 3 presents the same ratios for national and state-chartered banks in states that did not reduce their reserve requirements in the years 1913 through 1925. The cash ratios of the state-chartered banks declined about 5 to 6 percentage points during the period of rapid growth in the Fed's check-collection system, and these ratios remained at a new lower level throughout the 1920s. This pattern of change in the cash ratios of state banks in Figure 3, which is similar to the pattern in Figure 2, can be attributed to the Fed's collection system, since these states did not reduce their reserve requirements. The impact of the Fed's collection system is estimated at about 5 percent of the total assets of banks, which were liberated for other uses. ${ }^{21}$

\section{General Acceptance of Reserve Bank Payment Services}

Banks chose to use the Reserve Bank payment services, even though they were free to continue using the payment arrangements that had been available prior to the formation of the Fed. Acceptance of these services was rapid and on a large scale, indicating that the Reserve Banks met a demand for efficient interregional payment services that had been unmet through private arrangements. Banks would not have chosen to use Reserve Bank payment services if those provided by private parties had been more efficient.

\section{Elimination of the Markets for Domestic Exchange. Changes in the payments sys- tem that can be tied directly to Reserve}

${ }^{20}$ The numerator of the cash ratio includes the value of vault cash, balances with other banks, and CIPC. The denominator is total assets. Since banks held cash primarily to serve their customers who made payments out of demand deposits, a more ideal ratio might be cash to demand deposits. Data on the deposit liabilities of banks for the period covered in Figures 2 and 3 were of relatively poor quality, especially the division of deposits between demand and other deposits. See Board of Govemors (1959). For this reason, cash ratios in this article use total assets as the denominator.

${ }^{21}$ Another factor that might have influenced the cash ratios of banks around the time that the Fed developed its collection service was the financing of World War I. State-chartered banks increased their holdings of U.S. government securities substantially during the war, from less than half of 1 percent in 1916 to about 9 percent in 1918. With more liquid assets, banks may have been comfortable operating with lower cash ratios than before. The ratio of U.S. government securities to assets declined after 1918, however, falling to around 6 percent by 1929. If the securities holdings of banks explained their declines in cash ratios after 1916, we would expect the cash ratio to rise again after 1918, which did not happen. 


\section{Figure 2}

Ratio of Total Cash Assets to Total Assets:

States That Lowered Reserve Requirements, 1913-25

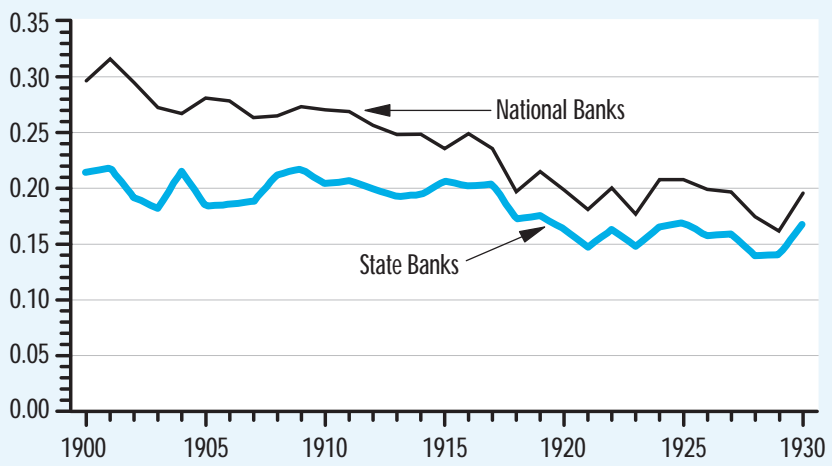

SOURCE: Board of Governors of the Federal Reserve Syster 95 ()/1

\section{Figure 3}

Ratio of Total Cash Assets to Total Assets: States That Did Not Lower Their Reserve Requirements, 1913-25

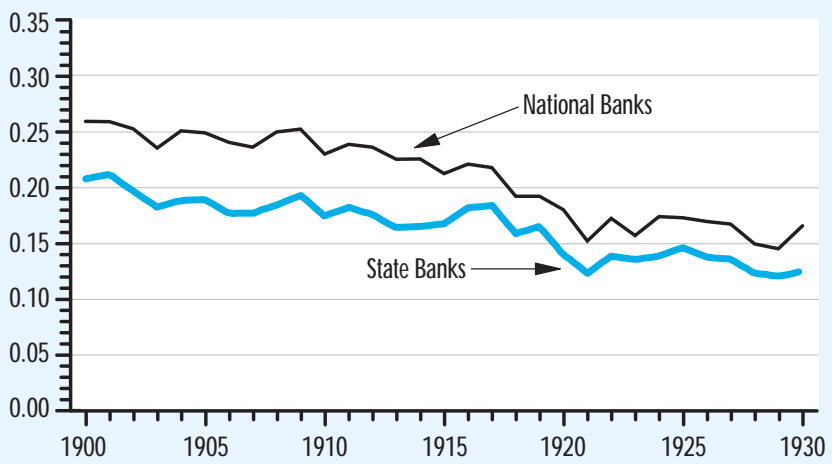

SOURCE: Board of Governors of the Federal Reserve System (1959).

${ }^{22}$ For analysis of network effects, see Katz and Shapiro (1994) and Economides and White (1994). the elimination of the markets for domestic exchange indicates that the most important factor was the opening of the Fed's wire transfer system, although access of member banks to reserves through the discount window may have limited the variation in exchange rates among cities.

\section{Network Effects and the Timing of} Growth in Fed Payment Services. The timing of growth in the Fed's collection system is consistent with the view that the Reserve Banks satisfied a demand for more efficient interregional check collection. In 1915, the dollar value of checks cleared by the Fed was only about 3 percent of the dollar value of checks cleared through the private clearinghouses. Under the voluntary system of 1915, member banks did not have to join the Fed's collection system. If they joined, however, they had to agree to pay at par when the Fed presented checks.

The limited response from banks to the F ed's offer of a voluntary collection service reflects the nature of the payments system as a network good. N etwork effects are exhibited when the demand by an individual customer depends on the number of other customers who use the good. ${ }^{22}$ While many banks might have viewed a par collection system as valuable in principle, the value of such a system to each bank would depend on the number of other banks that had agreed to join. When only a small percentage of banks agreed to pay the Fed at par, others had limited interest in joining. Why should they forgo some of their revenue from exchange charges if the new collection system could make par presentment to only a small percentage of banks?

The Fed changed its collection system substantially in 1916: All member banks were required to pay at par for checks presented by the Fed, and the Reserve Banks began charging the banks that deposited checks fees to cover their collection costs. The Reserve Banks' check-clearing volume began growing rapidly immediately after these changes were implemented.

The timing of this growth does not support the hypothesis that it occurred because the Reserve Banks had suspended the prac- 
tice of charging fees to depositing banks. The Fed's collection system had al ready grown to a relatively large share of national check collection by the time the Fed stopped charging collection fees in 1918. The Fed's share continued to rise after 1918, but at a slower pace than in the period from 1915 to 1918. The most important action to stimulate growth of its collection system appears to have been the Fed's decision to require all member banks to pay at par for checks presented by the Reserve Banks.

\section{Demand for a Par Collection Service and} the Geographic Location of Paying Banks. Critics of the payments system prior to the formation of the Fed acknowledged that check collection was efficient where collecting and paying banks were located in the same communities, but they wanted a more efficient mechanism for interregional check collection. If these critics were correct, banks would find the Fed's collection system valuable as a means of interregional check collection, not a mechanism for local collection.

In 1918, the Fed began reporting information on the location of the banks at which the Reserve Banks presented checks for collection. Table 2 indicates that only about 10 percent of the checks were presented to banks in the cities where the Fed had offices. Table 2 also indicates that the dollar denomination of checks presented to banks in cities where the Reserve Banks had offices was much larger on average than the size of checks drawn on banks located outside the Reserve Bank cities. These differences in the average dollar size of checks, which were pronounced in each of the 12 Districts, probably indicate that a relatively high percentage of the checks presented to banks where the Reserve Banks had offices involved interbank settlements rather than checks written by bank customers, since interbank reserve transfers tended to be much larger than most checks. ${ }^{23}$

\section{CONCLUSIONS}

Histories of the Fed's payment services generally focus on the Fed's failure to achieve its goal of getting all banks to participate in a national system for collecting checks at par. This article uses a different standard of evaluation: effects on the efficiency of the payments system. While the goal of universal par check collection remained out of reach for the Fed in its early years, evidence from the period when the Fed was founded suggests that the Fed's services improved payments system efficiency.

This analysis suggests that Reserve Bank payment services grew in popularity because they permitted banks to operate with lower ratios of cash to total assets. The relevant evidence is for banks chartered in states that did not reduce their reserve requirements around the time when the Fed was founded. Ratios of cash to assets for these banks declined about 5 percentage points during the period of rapid development in the Fed's payment services and then remained at the new lower level. For national banks and state-chartered banks in other states, changes in cash ratios reflect changes in reserve requirements, in addition to the effects of Reserve Bank payment services.

Banks chose to use the Fed's payment services rather than the payment arrangements that were available to them prior to the Fed's formation. By 1920 the Fed's wire transfer service had eliminated the old system of interregional settlement among banks, which had involved the use of drafts on N ew York City banks and the markets for domestic exchange. The share of checks cleared through the Reserve Banks rose dramatically after the Board acted in 1916 to require member banks to pay the Fed at par, despite the fee per check that each Reserve Bank began charging collecting banks in that same year. The Fed's checkcollection activities involved primarily interregional collection of checks, and banks found the Fed's system more attractive than the old system of collecting interregional checks through correspondents. The growth in the Reserve Banks' collections indicates that banks' demands for a national par collection service had been unmet prior to the Fed's formation.
${ }^{23}$ Transactions involving the Federal Reserve Bank of Boston and the Boston Clearing House Association (BCHA) illustrate the use of Reserve Bank clearing services for interbank settlement. In November 1914, the Boston Fed became a limited member of the BCHA. The manager of the BCHA opened an account at the Boston Fed for settlement among members of the clearinghouse. Members in net debit positions paid the managers of the BCHA with checks drawn upon their accounts at the Reserve Bank, and the manager paid the members in net credit positions with checks drawn upon the account of the $B C H A$ at the Boston Fed. The checks in Table 2 presented by the Boston Fed to Boston banks included the checks written by members of the $\mathrm{BCHA}$ to cover their net debit positions at the BCHA. 


\section{Table 2}

Local Checks and Other Checks Collected Through the Reserve Banks, 1918

\begin{tabular}{|c|c|c|c|}
\hline \multirow[b]{2}{*}{ District } & \multirow{2}{*}{$\begin{array}{l}\text { Percentage of Checks } \\
\text { Presented by a Reserve } \\
\text { Bank for Collection that Were } \\
\text { Draw n on Banks in Cities with } \\
\text { Reserve Bank Offices }\end{array}$} & \multicolumn{2}{|c|}{$\begin{array}{l}\text { Average Denomination of Checks } \\
\text { Draw n On Banks Located In: }\end{array}$} \\
\hline & & Reserve Bank Cities & Elsew here \\
\hline Boston & $10.8 \%$ & $\$ 2,613.5$ & $\$ 278.8$ \\
\hline New York & 9.0 & $7,336.7$ & 595.8 \\
\hline Philadelphia & 24.9 & $1,559.2$ & 360.2 \\
\hline Cleveland & 6.7 & $2,024.7$ & 586.7 \\
\hline Richmond & 4.4 & $3,311.0$ & 480.5 \\
\hline Atlanta & 12.1 & $1,278.5$ & 325.7 \\
\hline Chicago & 21.1 & $2,210.5$ & 221.0 \\
\hline St. Louis & 17.7 & $2,538.9$ & 241.2 \\
\hline Minneapolis & 14.7 & $2,682.9$ & 197.8 \\
\hline Kansas City & 6.2 & $3,128.1$ & 389.0 \\
\hline Dallas & 6.2 & $1,476.1$ & 369.2 \\
\hline San Francisco & 17.2 & $1,409.0$ & 245.9 \\
\hline System & 9.6 & $2,639.6$ & 496.3 \\
\hline
\end{tabular}

SOURCE: Annual Report of the Board of Governors, 1918.

\section{REFERENCES}

Bank for Intermational Settlements. Payments Systems in Eleven Developed Countries, Bank Administration Institute, 1989.

Baxter, William F. "Bank Interchange of Transactional Paper: Legal and Economic Perspectives," Journal of Law and Economics (October 1983), pp. 541-88.

Berger, Allen N., Diana Hancock, and J effrey C. Marquardt. "A Framework for Analyzing Efficiency, Risks, Costs and Innovations in the Payments System," Journal of Money, Credit and Banking (November 1996, Part 2), pp. 696-732.

Board of Governors of the Federal Reserve System. All-Bank Statistics, United States, 1896-1955, 1959.

Burgess, W. Randolph. The Reserve Banks and the Money Market, Harper \& Brothers, 1927.
Calomiris, Charles W., and Charles M. Kahn. "The Efficiency of Self-Regulated Payments Systems: Leaming from the Suffolk System," Joumal of Money, Credit and Banking (November 1996, part 2), pp. 766-97.

Cannon, James Graham. Clearing Houses, U.S. National Monetary Commission, Senate Document No. 491, 61st Congress, second session, Government Printing Office, 1910.

Canova, Fabio. "The Sources of Financial Crisis: Pre- and Post-Fed Evidence," International Economic Review (August 1991), pp. 689-713.

Clair, Robert T., Joanna 0. Kolson, and Kenneth J. Robinson. "The Texas Banking Crisis and the Payments System," Economic Review, Federal Reserve Bank of Dallas (First Quarter 1995), pp. 13-21.

Clark, Truman A. "Interest Rate Seasonals and the Federal Reserve," Journal of Political Economy (February 1986), pp. 76-125.

Comptroller of the Currency. Annual Report, Vol. 1, December 7, 1914, Washington, Government Printing Office, 1915. 
Annual Report, December 1, 1890, Washington, Government Printing Office, 1890.

Duprey, James N., and Clarence W. Nelson. "A Visible Hand: The Fed's Involvement in the Check Payments System," Federal Reserve Bank of Minneapolis Quarterly Review (Spring 1986), pp. 18-29.

Dwyer, Gerald P., and R. Alton Gilbert. "Bank Runs and Private Remedies," this Review (May/ June 1989), pp. 43-61.

Economides, Nicholas, and Lawrence J. White. "Networks and Compatibility: Implications for Antitrust," European Economic Review (April 1994), pp. 651-62.

Federal Reserve Board. Second Annual Report, U.S. Government Printing Office, 1916.

Fishe, Raymond P.H. "The Federal Reserve Amendments of 1917: The Beginning of a Seasonal Note Issue Policy," Journal of Money, Credit and Banking (August 1991), pp. 308-26.

and Mark Wohar. "The Adjustment of Expectations to a Change in Regime: Comment," American Economic Review (September 1990), pp. 968-76.

Garbade, Kenneth D., and William L. Silber. "The Payment System and Domestic Exchange Rates: Technological Versus Institutional Change," Journal of Monetary Economics (January 1979), pp. 1-22.

Garvy, George. Debits and Clearings Statistics and Their Use, Board of Governors of the Federal Reserve System, revised edition, 1959.

Gilbert, R. Alton. "Effectiveness of State Reserve Requirements," this Review (September 1978), pp. 16-28.

Hallock, James C. Clearing Out-of-Town Checks in England and the United States, 1903.

Harding, W.P.G. Report to the U.S. Senate on "State Banks in Federal Reserve System," Senate Document No. 184, 66th Congress, 2nd Session, January 26, 1920.

. . . . . The Formative Period of the Federal Reserve System, Houghton Mifflin C0., 1925.

Holland, A. Stephen, and Mark Toma. "The Role of the Federal Reserve as 'Lender of Last Resort' and the Seasonal Fluctuation of Interest Rates," Journal of Money, Credit and Banking (November 1991), pp. 659-76.

Howard, Earl Dean, and Joseph French Johnson. Money and Banking, DeBower-Eliott Co., 1910.

James, John A. Money and Capital Markets in Postbellum America, Princeton University Press, 1978.

Jessup, Paul F. The Theory and Practice of Nonpar Banking, Northwestern University Press, 1967.

Jones, Thatcher $\mathrm{C}$. Clearings and Collections; Foreign and Domestic, Columbia University Press, 1931.

Katz, Michael L., and Carl Shapiro. "Systems Competition and Network Effects," Joumal of Economic Perspectives (Spring 1994), pp. 93-115.
Magee, James D. "The Fight Against Par Check Collection," The Journal of Political Economy (June 1923), pp. 433-45.

Mankiw, N. Gregory, Jeffrey A. Miron, and David N. Weil. "The Adjustment of Expectations to a Change in Regime: A Study of the Founding of the Federal Reserve," American Economic Review (June 1987), pp. 358-74. , and _._._. "The Adjustment of Expectations to a Change in Regime: Reply," American Economic Review (September 1990), pp. 977-79.

Miron, Jeffrey A. "Financial Panics, the Seasonality of Nominal Interest Rates, and the Founding of the Fed," American Economic Review (March 1986), pp. 125-40.

Phillips, Ronnie J. "Payments System Technology and Central Banks: Early Lessons from the Federal Reserve and the Reichsbank," mimeo., Colorado State University, May 15, 1997.

Preston, Howard H. "The Federal Reserve Banks' System of Par Collection," The Journal of Political Economy (July 1920), pp. 565-90.

Rivlin, Alice M. "Testimony before the Subcommittee on Domestic Monetary Policy of the Committee on Banking and Financial Services," U.S. House of Representatives, September 16, 1997.

Rolnick, Arthur J., Bruce D. Smith, and Warren E. Weber. "Lessons From a Laissez-Faire Payments System: The Suffolk Banking System (1825-1858)," this issue of the Review.

Scherer, F. M. Industrial Market Structure and Economic Performance, Rand McNally College Publishing Co., 1970.

Spahr, Walter E. The Clearing and Collection of Checks, The Bankers Publishing C0, 1926.

Stevens, Ed. "The Founders' Intentions: Sources of the Payments Senvices Franchise of the Federal Reserve Banks," Financial Services Working Paper 0396, Federal Reserve Bank of Cleveland, December 1996.

Summers, Bruce J., and R. Alton Gilbert. "Clearing and Settlement of U.S. Dollar Payments: Back to the Future?" this Review (September/ October 1996), pp. 3-27.

Tippetts, Charles S. "The Par Remittance Controversy," American Economic Review (December 1924), pp. 629-48. . State Banks and the Federal Reserve System, D. Van Nostrand Co., Inc, 1929

U.S. Department of Commerce. Historical Statistics of the United States: Colonial Times to 1957 (1960).

Vest, George B. "The Par Collection System of the Federal Reserve Banks," Federal Reserve Bulletin (February 1940), pp. 89-96.

Weinberg, John A. "The Organization of Private Payment Networks," Federal Reserve Bank of Richmond Economic Quarterly (Spring 1997), pp. 25-43.

White, Eugene Nelson. The Regulation and Reform of the American Banking System, 1900-1929, Princeton University Press, 1983.

Willis, H. Parker. The Federal Reserve System: Legislation, Organization and Operation, The Ronald Press Co., 1923. 


\section{REVIEW \\ MAY / JUNE 1998}

and William H. Steiner. Federal Reserve Banking Practice, D. Appleton and Co., 1926.

Willis, Parker B. "The Background of the Par Collection and Clearance Provisions of the Federal Reserve Act and Some Features of the Par Collection Controversy," mimeo, Federal Reserve Bank of Boston, September 20, 1951. 
This appendix provides details on changes in federal and state reserve requirements that occurred more or less simultaneously with the introduction of the Federal Reserve System, because such changes allow us to draw conclusions about the effects of Reserve Bank services on banks' ratios of cash to total assets. Under the Federal Reserve Act (FRA), national banks were required to become members of the Federal Reserve System, and the FRA reduced reserve requirements for national banks substantially. Just prior to FRA's passage, reserve requirements were 25 percent of total deposits for national banks in central reserve cities (three major financial centers) and reserve cities (other important regional financial centers), and 15 percent for national banks located elsewhere (commonly called the "country" national banks). Banks in central reserve cities were required to hold all of their reserves as vault cash, whereas those located in reserve cities could hold up to half of their reserves as deposits at banks in central reserve cities, and country banks could hold 60 percent with banks located in reserve cities or central reserve cities.

Under the FRA, as enacted in 1913, reserve requirements for $\mathrm{Fed}$ members were different for demand and time deposits. For all member banks, the reserve requirement on time deposits was 5 percent, while the requirements on demand deposits were as follows: for banks located in central reserve cities, 18 percent; for those located in reserve cities, 15 percent; and for country member banks, 12 percent. As described in the text, calculations by the Comptroller of the Currency (1915) indicated substantial reductions in reserve requirements for national banks under the FRA.

It is difficult to estimate the effect of these changes on the cash assets of national banks, for the following reasons: Under the 1913 version of the FRA, only vault cash and balances at the Fed counted as part of reserves; balances with other banks were excluded from reserves. This exclusion of interbank balances limited the effects of the

\begin{tabular}{ll} 
Table A 1 & \\
States That Lowered Their \\
Reserve Requirements, \\
\cline { 1 - 2 } $1913-25$ & \\
\cline { 1 - 2 } California & New Mexico \\
Delaware & New York \\
Georgia & Oklahoma \\
Idaho & Oregon \\
Illinois & Pennsylvania \\
Indiana & South Dakota \\
Kansas & Texas \\
Kentucky & Virginia \\
Louisiana & Washington \\
Michigan & West Virginia \\
Minnesota & Wisconsin \\
Montana &
\end{tabular}

SOURCE: White (1983).

lower reserve requirements on the demand for cash by country national banks and national banks located in reserve cities in two ways. First, any collected balances that these national banks held with other banks did not count as reserves. In addition, the new requirements eliminated the practice of counting uncollected funds as part of reserves. For banks that collected checks through the Reserve Banks, uncollected funds were classified as cash items in the process of collection and, therefore, were not counted as part of reserves.

Fed reserve requirements were reduced again in 1917. On time deposits of all members, they were reduced from 5 percent to 3 percent. On demand deposits, they were reduced for banks in central reserve cities, from 18 percent to 13 percent; for banks in reserve cities, from 15 percent to 10 percent; and for country banks, from 12 percent to 7 percent. These changes had an offsetting effect on the demand for cash by member banks: Vault cash no longer counted as reserves; only balances in reserve accounts at the Reserve Banks were officially designated reserves.

Thus, the reserve requirement changes at the federal level were large, and their 
effects on the demand for cash by member banks were so complex that it would be difficult to separate them from other effects, such as the Fed's collection service. Another possible approach is to examine changes in cash ratios of state banks around the time the Fed developed its payment services. About half the states lowered their reserve requirements around the time the Fed was founded, as indicated in Table A1. These state actions can be treated as an experiment. The issue is whether the ratios of cash to assets declined for state banks in those states that did not lower their reserve requirements around the time the Reserve Banks developed their payment services. The text presents the evidence on this experiment. 